\title{
Influence of Motivation and Language Learning Environment on the Successful EFL Learning
}

\author{
Masyhur \\ National University of Malaysia, Bangi, Malaysia; \\ Riau University, Riau, Indonesia
}

\begin{abstract}
This case study investigates the influence of motivation and language learning environment on successful English as a foreign language (EFL) learning. The research examines: (1) the nature of the motivation of successful EFL learners; and (2) how language learning environment affects their success. The data are obtained from six EFL learners identified as successful learners based on their high-level English language proficiency and in their overall success of the language use. The EFL motivation is conceptualized and illustrated as a dynamically changing construct that plays important roles in the EFL learning process. The design of the study involves both holistic and focused analysis. Each participant's learning history is created through individual interviews. The research traces each participant's learning history, including motivational changes and salient motivational sources, such as their learning environments. The results show that the sustained motivation is not always present in successful EFL learning. The six learners' successes result from their ability to sustain their learning commitment. The research also reveals that a supportive parental family environment affects their success in the EFL learning. It is not only a feature found in the participants' birth families, but it also presents in the new families they gained after marriage. The findings provide important knowledge to language learners, language educators, and policy-makers about the critical role of motivation and commitment in EFL, in particular, in contexts where the majority of learners fail to attain high-level of language proficiency despite many years of informal or formal language study.
\end{abstract}

Keywords: dynamic motivation, learning histories, successful English as a foreign language (EFL) learning

\section{Introduction}

These are the conditions found in many provincial areas of Indonesia. Government and international donors have long complained of inadequate levels of English among university graduates (Sinclair \& Webb, 1985; Priyadi \& Ismuadi, 1998). The data from some universities in Sumatra indicate that about $75 \%$ students enter university without more than elementary level proficiency, even after six years of English at school (Lamb, 2002). The universities rarely provide more than four credits (64 hours maximum) of English instruction for non-English majors with the result that students are unable to read the English language textbooks in their subject areas. Thereby, they denied access to further language learning opportunities (as well as contemporary subject knowledge), and finally, enter the labor market without the economically valuable asset of English proficiency.

Masyhur, TESL Ph.D. student, Faculty of Education, National University of Malaysia; lecturer, English Study Program of Teacher Training and Education Faculty, Riau University. 
Despite all the facts mentioned above, researchers have revealed many English as a foreign language (EFL) learners who have been successful in the histories of their English language learning (Stevick, 1996). These learners, despite the odds, have succeeded in achieving a degree of communicative competence in English. This similar situation has also occurred in the EFL Indonesian context (e.g., in Riau Province). Although few in number, there are successful EFL learners in the province who have managed to become competent in the English language.

Researchers attribute the learners' success mostly to motivation. As a result, there has been an increase in research interest for the past 40 years on language learning and has important implications on EFL learning success in both classroom and naturalistic learning environments. Recent work, such as Dörnyei, Csizér, and Németh (2006) emphasized the dynamic nature of motivation. Motivation not only changes through the different phases of language learning, but it can also fluctuate within a relatively short time interval due to the influence of external and internal factors (p. 473). While many studies have examined motivation as a learner trait at one point in time (Chen, Warden, \& Cheng, 2005; Bernaus \& Gardner, 2008), few studies (Dörnyei \& Csizer, 2005; Gao, Y. Li, \& W. Li, 2002) had examined changes in motivation over time. The present research, therefore, aimed at examining in depth the motivation changes of a few EFL successful language learners in Riau Province, Indonesia. The emergence, source, ways, order, and time of motivation of their English language learning histories were examined in depth. If it can be discovered what enabled these few individuals to transcend the contextual constraints, we may be able to better help the majority who fail to do so, and who carry the burden of their failure with them throughout their working live. The objectives of the present research are:

1. Seeking to display successful learners' dynamic motivational changes and their learning histories from the first time they studied English until the achievement of highly proficiency;

2. It also aims to examine how these learners have sustained their learning motivation while studying in EFL environments.

While the two research objectives guide the overall study, several associated specific objectives were pursued. The objectives are associated with "When the most intensive learning took place?" "What learning strategies were employed?" "Why intensive learning took place during those particular period(s)?” and other relevant issues that might have influenced their learning, such as their family environment, influential people, and their interest other than English.

\section{Literature Review}

A study of foreign adults learning Norwegian was carried out by Svanes (1987) in Norway. She found that European and American students were more integratively motivated than the Middle Eastern, African, and Asian students who were found to be more instrumentally motivated. Svanes (1987) reflected that westerners could have "luxury motives for coming to Norway to study," whereas for students from developing countries their motivation is "to get an education.” In Svanes' study, there was also a significant difference in the grades recorded, with Europeans having the best and Asian students the poorest scores. According to Svanes and corresponding to Dörnyei’s (2000) findings, this indicates that integrative motivation rather than instrumental motivation may lead to better proficiency. He pointed out that familiarity with the culture and the language would make it easy to communicate and learn the language. Svanes (1987) maintained that such a closeness in culture developed an integrative motivation towards the target language culture, which fits in with Schumann's (2001) theory that the social distance an L2 learner has with the target language (TL) community is a major 
factor in language learning. Asian women were found to be significantly less instrumentally motivated than Asian men, but no such differences were found among the other groups. Such a low instrumental motivation could be due to lack of opportunities for women at least until recent times. No survey has been done which looks at his factor in the Japanese context in particular, but there is a good chance that this difference may also exist here.

In a recent study, Schmidt, Boraie, and Kassabgy (1996) investigated learners of English in an adult EFL setting in Cairo. Egypt would be representative of the developing countries that Svanes (1987) talked about in Dörnyei’s research, the difference being that these learners were "on home turf.” The authors were interested in finding out "what spurs thousands of Egyptians to exert the effort required and pay the fees for private instruction in English." Schmidt found a significant instrumental motivation which compared to Dörnyei's (2000) study. Schmidt (1995) argued that instrumental factors were important for adults who had chosen to study English privately in contrast with young learners who took English as a school subject and who were not yet faced with career choices or the need to be concerned with making a living.

The remaining studies deal with younger learners at the secondary and university level. Clement, Dörnyei, and Noels (1994) looked at secondary-level Hungarian students. They found that although these learners viewed English as an ordinary school subject with few chances for communication with the target culture on a personal level, they did think that contact with English was possible through the media and technology and English was widely recognized as the lingua franca of international communication. They found an instrumental orientation based on the acquisition of knowledge, rather than on the achievement of pragmatic outcomes and an integrative one based on expected foreign friendships through travel and an interest in English culture. This anticipated contact in the study resembles that of the adult learners in Dörnyei's (2000) previously cited study, indicating that adults and younger learners in an EFL context share similar integrative orientations.

The researchers concluded the instrumental-knowledge orientation in the integrative motive and put an end to what they and Oxford (1990) consider the "misleading use of a simplistic integrative-instrumental dichotomy." They also found two other motivation components for linguistic: self-confidence and classroom group dynamics. They argue that group dynamics in the classroom have particular relevance to L2 instruction since communicative methodologies stress interaction among learners. Oxford (1990) had stressed the need for longitudinal studies in order to monitor developmental changes in learners' motivation. Two studies, one by Teweles (1996) and the other by Berwick and Ross (1989) were longitudinal in nature.

However, although Teweles (1996) claimed his study to be part of a longitudinal study, he failed to point out any changes that occurred during the period of the study and indeed did not mention how long the study itself was. Teweles (1996) found differences between Chinese and Japanese university students with the Japanese showing more of an integrative motivation than the Chinese who showed more of an instrumental motivation. This difference in motivations between the Japanese and Chinese learners is partly explained by the fact that English assumes a very specialized role in the Chinese context with courses offered in connection with special interests, such as business English. But it could also have something to do with the difference of Svanes's (1987) founding, as Japanese learners are way more affluent than their Chinese counterparts and perhaps also feel less of a social distance with the west. Berwick and Ross' (1989) commented that there was a considerable decline in "instrumental interest" once the college entrance exams are over, as the reason Japanese students tended to score higher in integrative motivation.

Berwick and Ross (1989) assessed the motivation of university students at the beginning and end of their freshmen year. Their analysis indicated a limited development of an orientation towards personal growth 
through widening of their horizons and a desire to study abroad. While they support the idea that it is difficult to bring students back from the boredom of exam fever, they also maintain that the curriculum is at fault by not being relevant to learners' needs and motives for language study. They contrast this "motivational vacuum" with the extraordinary interest in language learning among adults in Japan and emphasize that universities must do much more to motivate students in this direction.

Greer (1999) claimed that a motivation survey of Japanese female junior college students he taught was a useful tool in curriculum development. By understanding why students learn English, he used the results to shape the course of classes he taught especially when choosing textbooks or deciding how much conversation practice to do. He had found that integratively motivated students responded better to texts weighted towards conversation and more instruction. The majority of students (68\%) he surveyed were integratively motivated.

In a comparative study, Okada, Oxford, and Abo (1996) found that the motivation of American learners of Japanese was far greater than that of learners of Spanish and concluded that motivation must be higher when one tries to learn a more difficult language, because greater persistence and determination are needed to cope with the stress of a difficult situation. Conversely, one might assume that for EFL learners in Japan, English is a difficult language to learn, and so, such persistence and determination must also be present in order for language learning to be successful.

However, this is rarely the case and unlike the USA where generally the motivated and able students choose to study Japanese. In Japan, everyone has to learn English, so teachers have to search for ways to motivate these less able students. It could be argued that one way to motivate these less able students is to offer incentives. Gardner (2001) studied the effects of both instrumental and integrative motivation among university students. Results showed that both types of motivation facilitated learning, but that those who were instrumentally motivated studied longer than those who were integratively motivated. They offered financial incentives for high-performance on vocabulary tests and found that when the incentive was removed, students stopped applying more effort. Gardner and Mclntryre (1991) stressed this as being the major disadvantage of such instrumental motivation, but add that if the goal is continuous, instrumental motivation would continue to be effective.

Dörnyei (2000) stressed that the question of how to motivate students was an area on which L2 motivation has not placed sufficient emphasis in the past. He pointed to the lack of research into extrinsic motives, such as grades and praise. Financial incentives, such as those offered by Gardner (2001) were not often feasible, but other types of incentives, such as certificates may work well especially with younger learners. Access to the Internet and other media, such as newspapers and magazines in schools may take advantage of the "acquisition of knowledge" factor which Dörnyei (2000) found to be important for the students in his study. Such knowledge can be seen as "intrinsic motivation" or motivation brought about by the stimulating or interesting presentation of the subject of study itself, an area where the teacher has the most influence and is therefore of paramount importance. However, as Ellis (1994) noted, there had been very little systematic research of the effects which pedagogic procedures had on motivation.

This lack of focus on intrinsic motivation has been borne out by the studies in this section. Intrinsic factors have been touched on but not the focus of research. As it has been found by Chihara and Oller (1970), intended contact of some nature with the target culture played an important role in motivation, a combination of strategies to motivate learners integratively and intrinsically was probably the key to enhancing language performance. Indeed, Berwick and Ross (1989) maintained that motivation to learn a language can be expanded 
by offering programs that offer attainable short-term goals, exchange programs with foreign colleges, short-term homestay programs overseas, and programs with foreign students in Japan. These would seem to be a combination of intrinsic and integrative factors.

Oxford (1990) contended that intrinsic motivation in the form of the classroom experience can be a big determiner in motivating power. With Okada, Oxford, and Abo (1996) maintained that it was desirable to use activities in the classroom that "engage and enhance the learners' motivation.” They considered that learners were not just interested in language but also in culture. Therefore, motivation might be stimulated by weaving culture into classes more effectively in the form of "content of conversations, tapes, readings .... Socio-linguistic aspects, cultural elements in games, simulations, and role plays, which also reduce anxiety.”

Dörnyei (2000) recommended 30 different ways to promote motivation among students. These serve as a very practical checklist for teachers, covering areas related to language, learner, and learning situation plus teacher- and group- specific motivational components. As teachers in the foreign language classroom, we have to be aware of the kinds of motivations the students bring with them, but we also have to be aware of our own power to enhance those motivations and/or introduce different kinds which will further develop language learning.

\section{Methodology}

This study employed a multiple case study as suggested by Yin (2009). To this end, presenting a comprehensive case study protocol is crucial in this case. A case study protocol is applied in order to describe the process which was followed throughout the study and it included aspects of the study that were added and altered as the study proceeded. Specifically, information concerning the case study design, participants, instrumentation, interviews, follow-up e-mail messages, case study questions, analysis, and case study report, are presented in the protocol.

Table 1

Participants' Backgrounds

\begin{tabular}{lllllll}
\hline Name & Gender & $\begin{array}{l}\text { Age of starting to } \\
\text { learn English }\end{array}$ & $\begin{array}{l}\text { Total time studying } \\
\text { English }\end{array}$ & $\begin{array}{l}\text { Highest TOEFL } \\
\text { score }\end{array}$ & $\begin{array}{l}\text { Highest } \\
\text { TOEIC score }\end{array}$ & $\begin{array}{l}\text { Estimated written } \\
\text { receptive vocabulary size }\end{array}$ \\
\hline Dinda & Female & 12-year-old & 26 years & 630 & NA & 12,700 \\
Athalla & Male & 12-year-old & 33 years & NA & 950 & 12,700 \\
Pathia & Female & 13-year-old & 13 years & NA & 920 & 11,500 \\
Ratna & Female & 13-year-old & 39 years & $270(\mathrm{CBT})$ & 990 & 13,200 \\
Indra & Male & 13-year-old & 40 years & NA & NA & 13,200 \\
Putri & Female & 10 -year-old & 19 years & $283(\mathrm{CBT})$ & 980 & 10,000 \\
\hline
\end{tabular}

The participants were the following six persons using pseudonyms, which were used based on those participants' requests: Dinda, Athalla, Pathia, Ratna, Indra, and Putri. They are highly proficient in English proved by their test of English as a foreign language (TOEFL)/test of English for international communication (TOEIC) scores and estimated written receptive vocabulary sizes. Table 1 presents the backgrounds of the six participants.

All the participants were native speakers of Bahasa Indonesia and were English instructors working in the same English faculty in a state university located in Riau Province. Some of them were lecturers and others were part-time university instructors in more than one educational institution. A salient characteristic of the six 
participants was their advanced English speaking ability. Some university English instructors in Riau are unable to speak English well even though they are able to teach English (e.g., grammar and reading), but this was not the case with the English faculty in the department. This occurred because the head of the department had extensive English teaching experience in a number of language schools before becoming a university lecturer and he recruited most of the new instructors utilizing his own personal network when he was put in charge of creating a new faculty, not through publicly posting the positions. As a consequence of this unique recruiting process, the new faculty members had advanced English-speaking proficiency. Furthermore, they came from a variety of backgrounds, which was another advantage of choosing research participants from this group.

\section{Results and Discussions}

There are three issues discussed, which emerged from the collective analysis of the six case studies of the participants' English learning histories. Firstly, fundamental issues concerning the characteristics of the participants are emphasized: their motivational development and their learning. Secondly, the exploration focuses on seven motivational sources salient in the participants' English learning histories. Thirdly, there is an examination of the initial proposition 1 concerning the participants' sustained motivation and discussed a new concept—commitment to learning.

\section{Fundamental Issues}

The six case studies revealed that the participants were not special learners who were destined to consistently possess high-level of learning motivation and become highly proficient in English. Rather, at the onset of their English study, they were indistinguishable from many students found in English classrooms across Indonesia, because they were from middle class families, their parents were not proficient in English, and they did not visit or live in an English-speaking country in their childhood. Most of them began studying English as a school subject at the age of 13 in a junior high school, and they studied to pass entrance examinations in their final years in junior high school and high school.

Academically, they were generally not exceptional students who were the top of their class in elementary and secondary school. English was not their only interest and they were involved in many other activities, such as playing music and sports, watching movies, painting, reading, writing, studying science and Japanese, and spending time with their friends. The participants' broad interests indicate that English learning represented just one of their interests. Despite the impression that they were unexceptional in most respects, the participants became exceptional English learners. Why was this possible? Did this happen partially because of the participants' innate traits and partially something they learned from the environment? Though the issue concerning the ratio between the inherited and the learned is hard to speculate and beyond the scope of this study, research on the development of expertise provides a clue to the answer to the question. A number of researchers have reported that an extended number of years of intensive practice of an activity is essential to achieve expertise in a field (Bloom, 1985; Erricsson, Tesch-Römer, \& Krampe, 1990, which was true with the participants in this study. They prioritized acquiring English and they studied intensively for an extended period of time, both of which differentiated them from most other English foreign learners. The participants' perseverance was a primary reason for their exceptional achievement. 


\section{Salient Motivational Sources}

In this section, seven salient motivational sources in the six participants' learning histories are discussed. Salient means: 1 . The motivational source appeared in four or more of the six case studies; or 2. Fewer than four but the issue was important to those participants. Five of these motivational sources: personal disposition, key people, internally emergent motivation, external goals, and authentic communicative experiences using English, played generally positive roles. In contrast, the final two motivational sources: national examinations and classroom experience, influenced the participants generally negatively.

\section{The Key to Success in Foreign Language Learning}

In this section, the key to successful foreign language learning is discussed. In the first half, the initial underlying proposition of this study—successful learners have experienced motivational declines at least once, but they overcome such setbacks-is examined over the six case studies. After re-considering the notion of sustained motivation, a new assumption concerning the key to successful foreign language learning is presented.

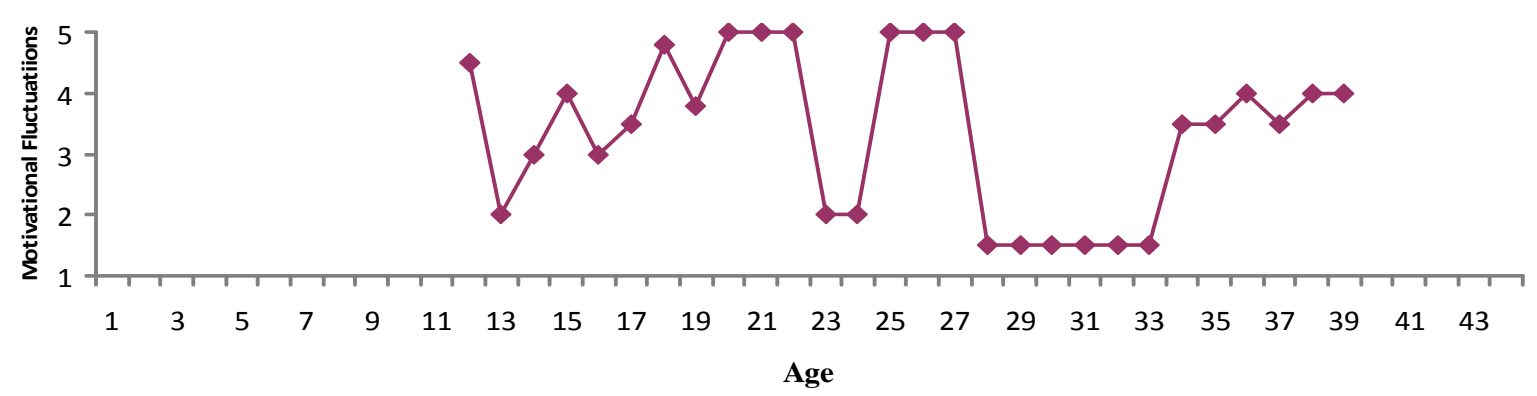

Figure 1. Dinda's motivational fluctuations.

Dinda stated that her motivation repeatedly increased and decreased, and that high-level of motivation were not sustained for longer than three years (see Figure 1). The primary pattern she displayed in her English study was based on goal achievement: She experienced a sharp motivational increase before achieving the goals and a sharp decline after attaining them. Dinda stated that she never particularly liked English, but she believed that English was a necessary tool in her quest to achieve other goals, such as enrolling in a good public high school, studying for the university entrance examinations, and enrolling in and academically succeeding in her undergraduate program and graduate program in the USA. She studied English with great intensity in order to achieve these goals. Therefore, her English learning motivation inevitably rose when she targeted a goal that required English skills and diminished when she achieved the goal.

Athalla's major motivational increase and decrease happened at the ages of 24 and 26 (see Figure 2). The first motivational decrease took place at the age of 24 after he graduated from his university. He abandoned his hope to become a professional musician, but he did not have a specific alternative in mind for a while. As he was not serious about a future profession, he worked as a telex operator for two years after graduating from the university. At the age of 26, his motivation resurged when he ended his moratorium period and decided to become a fully engaged in mainstream society. When considering a possible professional goal, he selected an English-related profession and reentered the university to study English literature. Because his academic and professional pursues were related to English, he was motivated to improve his English skills. 


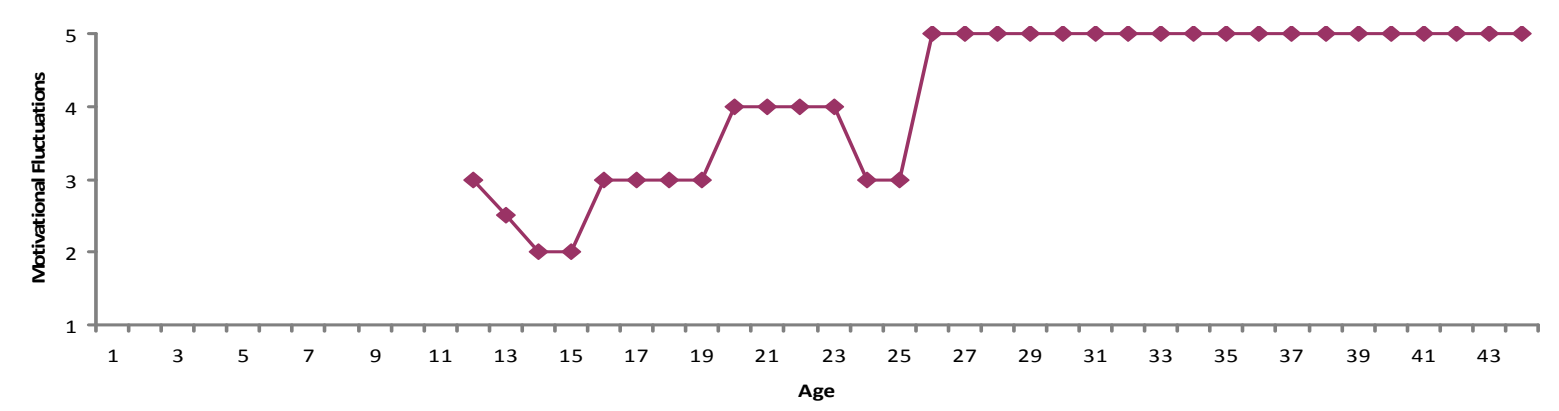

Figure 2. Athalla's motivational fluctuations.

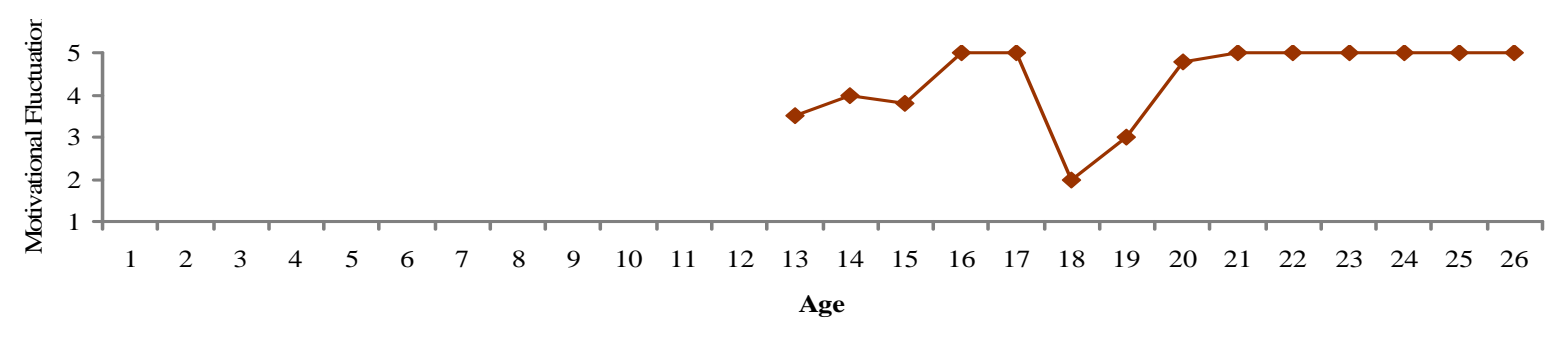

Figure 3. Pathia's motivational fluctuation.

Pathia's motivation noticeably declined at age 18 and began resurgence at the age of 20 (see Figure 3). Before this largest fluctuation occurred, her motivation increased to all time high at the age of 17 when she participated in a two-week study abroad program in the USA. Because of the impact from that study abroad program, she wished to study English intensively to become a good English speaker after enrolling in the university she wanted to attend. However, she temporarily postponed her desire, because she had to study for the university entrance examinations for the entire next year. Her motivational decline happened because of the negative washback of the university entrance examinations. After being free from the intensive studying for the entrance examinations, she allowed herself to enjoy a more relaxed life as a university student. As a result, her English learning motivation was weakened and she did not seriously study English for the next two years. At the age of 20, visiting Australia triggered her learning motivation again.

Using English communicatively in an English-speaking country led her to regret the past two years during which her English did not improve at all. However, it also promoted her to recall her desire to become a good English speaker. This experience provided her with a strong impetus to study English, and she once again began to pursue her goal to become a good English communicator.

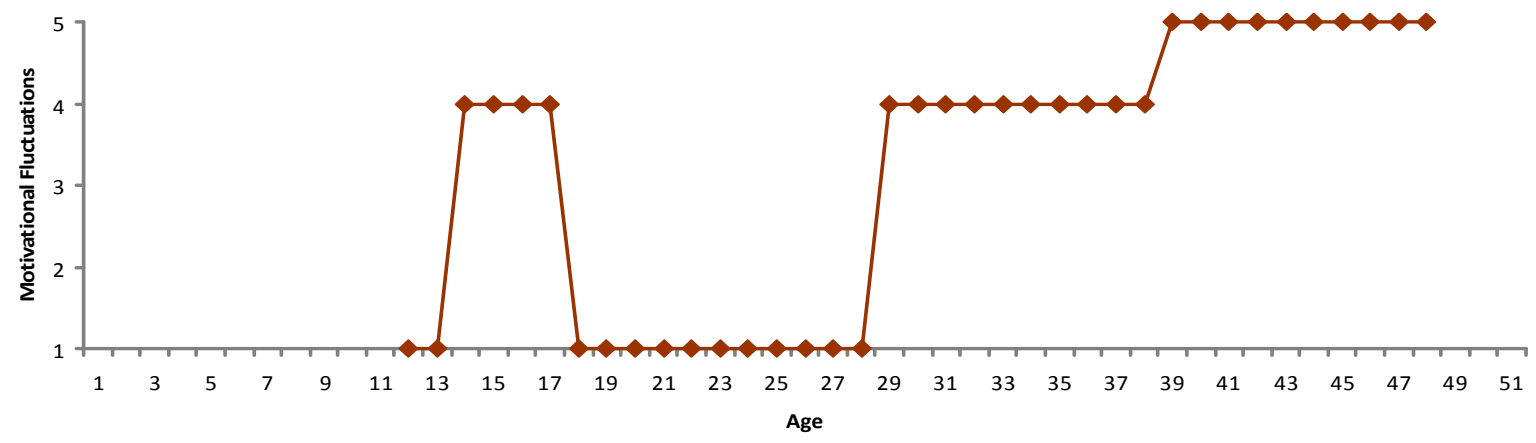

Figure 4. Ratna's motivational fluctuation. 
Ratna's motivational decrease took place at 18 and her motivational resurgence occurred when she was 29 (see Figure 4). The decrease occurred when she enrolled in the Japanese literature department in her university. Even though English was her favorite subject and she liked and was enthusiastic to study it in high school, it was merely one of many school subjects to her. After completing the university entrance examinations, English became nearly irrelevant in her life, a situation that continued for the next 10 years. After finishing her undergraduate studies, she worked at the city office for eight and a half years but was never satisfied with the job. While searching for a more interesting and challenging career, she encountered English again and her motivation to study was revived. English once again captured her interest and provided her with a new profession, teaching English. Since that time, she has been motivated to improve her English skills for the sake of her profession.

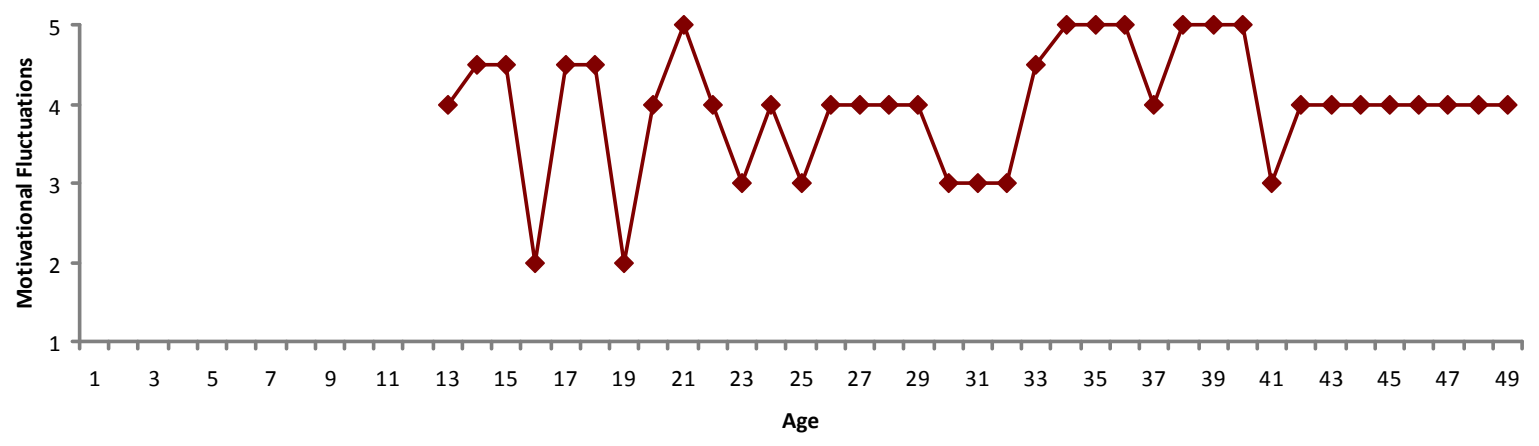

Figure 5. Indra's motivational fluctuation.

Similar to Dinda, Indra stated that his learning motivation rose and fell periodically. His motivation to study English emerged primarily internally and was based on his interest in English, learning English, and English related activities. Figure 5 illustrates his motivational fluctuations, which moved in accordance with the changes of his interest. Although his motivation temporarily decreased at the age of 16 after failing the high school entrance examinations and at the age of 18 after failing the university entrance examinations, his motivation resurged when he engaged in English-related activities that captured his interest, for example, studying English, especially memorizing a great deal of vocabulary in high school, speaking English and forming the English club at the age of 20, acting as a tour guide and interpreter and leading the student tour guide interpreter club at the age of 21, passing the tour guide test and teaching English at a language school at the age of 22 , and studying linguistics in graduate school at the age of 33. Each case clearly shows that every participant experienced at least one motivation decline followed by a subsequent resurgence in motivation. Thus, initial proposition 1 was supported by all six case studies. The participants potentially could have lost their learning motivation and not experienced its resurgence. Consequently, they would not have achieved a high-level of English proficiency, as is the case with the majority of English learners in Japan. This suggests that successful learners' advanced proficiency is a consequence of conquering motivational challenges that occurred in their long-term learning histories. The path to advanced proficiency in a foreign language is rough and winding, rather than smooth and straight. 


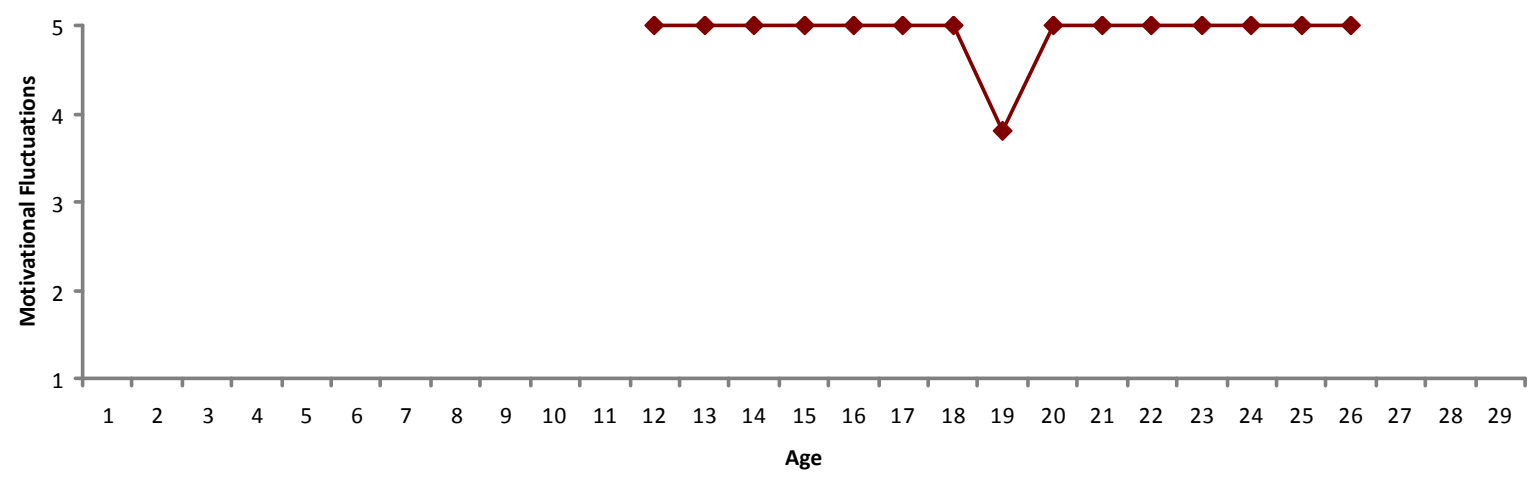

Figure 6. Putri's motivational fluctuation.

Putri's brief motivational fluctuation took place between the ages of 17 and 18 (see Figure 6). Her motivation has been constantly high, because her interest in English had never dwindled and she had selected an English-related career goal at the age of 15 by choosing to focus on English rather than the piano. However, a motivational decrease occurred because of the disappointing classroom experience she had in her university. At the age of 18 when she became a university freshman, she had to take a general English course with relatively unmotivated and lower proficiency students. Even though she had had a long-term English goal and had been motivated to study English in high school, her motivation was affected negatively when facing the demotivating class atmosphere. She felt that studying hard was neither encouraged nor appreciated in the class where few students tried to study hard. If she had experienced the same kind of course next year, her motivation might have been jeopardized further. However, her motivation resurged to its highest level the next year, because she obtained the qualification to take the intensive English course in the university. The class atmosphere was entirely different from the course she took the previous year: The students were highly motivated and a number of them aimed to study abroad. The course instructors were also enthusiastic and hard work was rewarded and valued. In addition, taking the course was an important step in applying to the study abroad program in her junior year. Therefore, her English learning motivation returned to its previous high-level.

\section{Applying the Motivation-Commitment Model to the Participants}

Finally, let us re-examine the participants' English learning histories, this time applying the motivation-commitment interaction model. The primary focus is on: 1 . the important motivational sources that underlie the formation and emergence of commitment; and 2. when English became important to the participants, as this provides a clue to the emergence of commitment. In addition, the participants' investment in activities involving studying English, prioritizing these activities over other alternatives, and the challenges they faced are also discussed. Because the concept of commitment emerged in the final phase of the data analysis, the author has never asked the participants about their commitment to learning. Thus, the following discussions are based on my interpretation of their learning histories as viewed through the lens of the motivation-commitment interaction model. In the following tables, the different parts from left to right schematize the formation and emergence of commitment in the participants and the motivational source(s) in bold are directly and immediately involved in the moment when English became important to each participant.

Dinda. Studying English became important for Dinda when she studied abroad at the ages of 17, 20, and 25. Her primary motivation was instrumental, as English was a tool for her to achieve her other goals that 
always required advanced English proficiency, because she was competing with native speakers of English. When necessary, she exerted a tremendous effort and studied intensively to "win the game," or to succeed in the academic programs in which she was enrolled. In particular, in the first one-year study abroad experience at the age of 17 and the second one when she attended the undergraduate program in the USA to study journalism at the age of 20, English was a crucial requirement, given that she would not have been able to participate in and complete these programs successfully without achieving advanced English abilities. In the beginning of both study abroad experiences, she faced linguistic, academic, and cultural challenges, which she overcame with unexceptional hard work. She prioritized achieving her goals to a degree that resulted in serious health problems. Although her commitment might not necessarily have been to learning English, the author believes that commitment to achieving her goals likely formed and emerged during these periods of studying abroad (see Table 2).

Table 2

The Formation and Emergence of Commitment in Dinda

Dnda's motivational sources:

1. Independent and self-understanding

2. Ability to concentrate

3. Family support

4. Key people

5. External goals that required English

6. Communicative experience

7. National Exam

English became important at the age of 17 when studying abroad, and at the age of 20 when applying for the Commitment to undergraduate program in US.

Athalla. English became important for Athalla at the age of 26 when he considered what academic and professional career he wanted to pursue. At the age of 26, he decided to return to his university to study English literature. Until that time, he had not considered his long-term goals realistically. He had valued English to a certain degree since he was a high school student, as he frequently read English novels and watched western movies, and he was inspired by his reading teacher in the university, but he studied English primarily to satisfy his own interest. In contrast, the decision he made at the age of 26 was more serious and associated with a professional goal, and he had continuously made an effort to improve his English skills. The author believes that his commitment to learning emerged with this decision (see Table 3).

Table 3

The Formation and Emergence of Commitment in Athalla

Athalla's motivational sources:

1. Independent

2. Ability to concentrate

3. Key people

4. Interest related to English

5. External goal with a new career vision

English became important at the age of 26 when he Commitment to considered academic and professional goal.

Pathia. English attained a special value for Pathia when she met and communicated with the American high school students at the age of 17 when studying abroad for the first time. Though she had liked English as a school subject in junior high school and she enrolled in the English course in high school, the impact she received from the experience in the study abroad program changed her perception toward learning English. Because her English communicative ability had not developed yet, participating in the communicative activities with the American students was a challenging experience for her. After this experience, the American students 
became role models whom she perceived in an idealistic way, and acquiring a high degree of English proficiency became the goal that she most wanted to achieve.

This goal was set autonomously and consciously by Pathia and was not based on encouragement from other people, such as her parents or teacher. Although it took Pathia several years to begin seriously pursuing her goal and investing a great deal of time and energy in English study due to the powerful negative wash back from the university entrance examinations, her commitment to learning likely started sometime around this event (see Table 4).

Table 4

The Formation and Emergence of Commitment in Pathia

Pathia's motivational sources:

1. Ability to concentrate

2. Family support

3. Internally emerged motivation

4. Communicative experiences

5. Key people

6. National exams

English became important at the age of 17 when she studied Commitment to abroad and had communicative experiences.

Ratna. English became important to Ratna at around the age of 29 when she resumed studying English at the end of her prolonged period of job searching. She had had a stable job she was not satisfied with and wished to quit for eight years. Working in the unsatisfying and frustrating situation, her psychological challenges gradually developed into physical health problems. She encountered English at this time again. Though her initial motivation was merely instrumental—she thought that passing the second level of the English test might help her find a new job, English soon became interesting and important to her. Unlike her high school period, English was not just one of her favorite school subjects. Acquiring English became an important goal that provided her with an interesting and challenging career. The intensive study, effort, and investment she made afterward to improve her English skills and developed her English teaching career indicated that her commitment to learning emerged at this time (see Table 5).

Table 5

The Formation and Emergence of Commitment in Ratna

Ratna's motivational sources:

1. Independent and optimistic

2. Ability to concentrate

3. Family support

4. Key people

5. Internally emerged motivation

6. An external goal

7. Communicative experience

8. National exams

English became important at age 29 when she resumed Commitment to

English study while searching a new professional goal. learning emerges

Indra. English became special for Indra at the age of 19 when he began speaking English for the first time in his university course. Having only studied reading, grammar, and vocabulary in high school, speaking English was novel and fascinating to him. Even though he was a fundamentally science-oriented person and his favorite subject had been physics, speaking English captured his interest, and he made an extraordinary effort to improve his speaking skills. It was a starting point for him to participate in a variety of English-related activities in which he used and improved his English speaking skills to establish English club, become a tour guide interpreter, teach English, publish English textbooks, and study linguistics. His exceptional effort to 
improve his English skills had not stopped since then. Thus, his commitment to learning might have begun to form at this time (see Table 6).

Table 6

The Formation and Emergence of Commitment in Indra

Indra's motivational sources:

1. Independent and self-understanding

2. Ability to concentrate

3. Family support

4. Key people

5. External goals that required English

6. Communicative experience

7. National Exam

English became important at the age of 17 when studying

English became important at the age of 17 when studying
abroad, and at the age of 20 when applying for the Commitment to undergraduate program in US. learning emerges

Putri. English became special for Putri at the age of 15 when she decided that her future career options related to English were more practical and achievable than the career as a professional pianist, though she had enjoyed and enthusiastically engaged in both activities since she was an elementary school student. Because of her family environment and her parents' support, she had been exposed to and had liked English since she was a child. However, her decision at the age of 15 to select an English-focused high school course increased the importance of English for her. While playing the piano became a hobby, increasing her English proficiency became a serious and concrete goal for her. After prioritizing English over the piano, Putri had invested a great deal of time and energy in developing her English skills. Thus, it was possible that her commitment to learning emerged after this event (see Figure 6). The entrance examinations-her commitment to learning likely started sometime around this event (see Table 7).

Table 7

The Formation and Emergence of Commitment in Putri

Putri's motivational sources:

1. Self-understanding and independent

2. Family environment

3. Parents' support

4. Key people

5. Internally emerged motivation

6. External goal with an academic and career vision

7. Communicative experience

8. Classroom experience

\section{Applying the Motivation-Commitment Model to English Learners in Riau}

The motivation-commitment interaction model allows us to perceive motivational development in foreign language learning from a new angle, which can help us better understand learners' motivational development and their eventual successes and failures in foreign language learning. For instance, important questions, such as why only a limited number of foreign language learners become proficient in English in spite of the fact that a large number of young learners are motivated to study the language, or why negative washback from taking the entrance examination occurs frequently in university students, can be explained by the model. Conventional wisdom suggests that these results occur, because the learners' learning motivation is too weak, but the model provides an alternative explanation: For the majority of English learners in Riau, English is not important in any realistic sense - they can carry on their lives without using English, and commitment to learning it is unlikely emerge in that context. Even if they are motivated to study English when they begin their formal 
education in the language or they think that English is important when studying for the entrance examinations while in middle school, they have not been intentional and autonomous about their learning to a degree that allows them to prioritize studying English over other important activities, to persist in their efforts to develop their English skills further, and to overcome the challenges they inevitably encounter. The motivation-commitment interaction model implies that acquiring a foreign language in an EFL context is not necessarily a task that "motivated" learners can achieve.

\section{Conclusions}

This multiple case study was an investigation of six highly proficient learners' motivational changes and their learning histories. Firstly, the results illuminate the complex and dynamic development of the participants' motivational fluctuation in the long-term process of foreign language learning. Each participant's learning history vividly shows that each individual's motivational development and learning history was fundamentally unique, because a number of motivational sources interacted with one another at different times, in different orders, and in different contexts. Secondly, the six case studies allowed the author to confirm an underlying proposition concerning successful learners' foreign language learning motivation the author made at the onset of the study: Successful learners have experienced one or more motivational declines but have overcome such experiences. This indicates that the path to acquiring high proficiency in a foreign language is a dynamic and challenging one in which motivational fluctuations are a common occurrence. Thirdly, searching for the keys to the participants' sustained motivation revealed seven salient motivational sources in their learning histories: the learners' personal dispositions, their family environment, internal factors, especially interest, external goals, their communicative experiences, especially those that occurred while studying abroad, the entrance examinations, and their classroom experiences.

What is more, exploring the participants' learning histories collectively led to the emergence of two new related findings regarding the key to successful foreign language learning. Firstly, sustained motivation is not always a prerequisite for achieving high-level of proficiency and in some cases is insufficient. Secondly, the emergence of commitment, which is an intentional, enduring psychological force, is more important in the long-term than what has been called motivation and is perhaps necessary in some learning contexts, such as those in which access to linguistic input and communicative opportunities are limited. The data gathered in this study suggest that one key to success in foreign language learning is commitment to learn, a cognitive change that emerged at some point in each of the participants' learning histories through the interaction of several motivational sources. This change always occurred after the participants perceived that English was important to them and sometimes involved challenges they had faced previously and wanted to overcome. Commitment is conceptualized as a key element in the motivation-commitment interaction model, and the participants' learning histories were reexamined using the model. The author proposes that the model plausibly explains the tremendous effort and extraordinary achievements the participants made in their acquisition of English. Motivation alone failed to completely explain these achievements. Centering the analysis on the learners' voices and their stories made these new insights possible.

\section{References}

Beglar, D. (2010). A rasch-based validation of the vocabulary size test. Language Testing, 27(1), 101-118.

Benson, P. (2004). Auto-biography and learner diversity. In P. Benson, \& D. Nunan (Eds.), Learners' stories: Difference and diversity in language learning (pp. 4-21). Cambridge: Cambridge University Press. 
Benson, P. (2006). Autonomy in language teaching and learning. Language Teaching, 40, 21-40.

Bernaus, M., \& Gardner, R. C. (2008). Teacher motivation strategies, student perceptions, student motivation, and English achievement. The Modern Language Journal, 92, 387-401.

Berwick, R., \& Ross, S. (1989). Motivation after matriculation; Are Japanese learners of English still alive MTER exam hell? JALT Journal, 11(2), 193-210.

Bjork, C. (2004). Decentralization in education in Indonesia. International Review of Education, 50, 245-262.

Bloom, B. (1985). Developing talent in young people. New York, N.Y.: Ballantine Books.

Brown, H. D. (2000). Principles of language learning and teaching (4th ed.). New York, N.Y.: Addison Wesley Longman, Inc..

Brown, J. D. (2005). Testing in language programs: A comprehensive guide to English language assessment. New York, N.Y.: McGraw-Hill.

Chen, J. F. Warden, C. A., \& Cheng, H. (2005). Running head: Motivators that do not motivate. TESOL Quarterly, 39(4), 609-633.

Chihara, T., \& Oller, J. (1978). Attitudes and attained proficiency in EFL: A sociolinguistic study of adult Japanese speakers. Language Learning, 28, 55-68.

Clement, R., Dörnyei, Z., \& Noels, K. (1994). Motivation, self-confidence, and group cohesion in the foreign language classroom. Language Learning, 44(4), 417-448.

Coon, D. (2001). Introduction to psychology: Gateways to mind and behavior (9th ed.). Belmont, C.A.: Wordsworth.

Creswell, J. W. (2007). Qualitative inquiry and research design: Choosing among five approaches. Thousand Oaks, C.A.: Sage.

Deci, E. L., \& Ryan, R. M. (2000). The "What” and “Why” of goal pursuits: Human needs and the self-determination of behavior. Psychological Inquiry, 11(4), 227-268.

Donitsa-Schmidt, S., Inbar, O., \& Shohamy, E. (2004). The effects of teaching spoken Arabic on students' attitudes and motivation in Israel. Modern Language Journal, 88(2), 217-28.

Dörnyei, Z. (2000). Motivation in action: Towards a process-oriented conceptualization of student motivation. British Journal of Educational Psychology, 70, 519-538.

Dörnyei, Z. (2001). Teaching and researching motivation. Harlow: Longman.

Dörnyei, Z. (2003). Attitudes, orientations, and motivations in language learning: Advances in theory, research, and applications. Language Learning, 53(1), 3-32.

Dörnyei, Z. (2005). The psychology of the language learner: Individual differences in second language acquisition. Mahwah, N.J.: Erlbaum.

Dörnyei, Z., \& Csizer, K. (2005). Language learners' motivational profiles and their motivated learning behavior. Language Learning, 55, 613-659.

Dörnyei, Z., Csizér, K., \& Németh, N. (2006). Motivation, language attitudes, and globalisation: A Hungarian perspective. Clevedon: Multilingual Matters.

Dörnyei, Z., \& Schmidt, R. (Eds.). (2001). Motivation and second language acquisition. Honolulu, H.I.: University of Hawaii Press.

Dörnyei, Z., \& Ushioda, E. (2011). Teaching and researching motivation (2nd ed.). Harlow: Longman.

Duff, P. A. (2008). A case study research in applied linguistics. Mahwah, N.J.: Lawrence Erlbaum.

Ellis, R. (1994). The study of second language acquisition. Oxford: Oxford University Press.

Ericsson, K. A., Tesch-Romer, C., \& Krampe, R. (1990). The role of practice and motivation in the acquisition of expert-level performance in real life: An empirical evaluation of a theoretical framework. In M. J. A. Howe (Ed.), Encouraging the development of exceptional skills and talents (pp. 109-130). Leicester, England: The British Psychological Society.

Falout, J., \& Maruyama, M. (2004). A comparative study of proficiency and learner demonization. The Language Teacher, 28(8), 3-9.

Gable, S. L., \& Haidt, J. (2005). What (and why) is positive psychology? Review of General Psychology, 9(2), 103-110.

Gao, Y., Li, Y., \& Li, W. (2002). EFL learning and self-identity construction: Three cases of Chinese College English Majors. Asian Journal of English Language Teaching, 12(2), 95-119.

Gardner, H. (2006). Multiple intelligences: New horizons. New York, N.Y.: Basic Books.

Gardner, R. C., \& MmacIntyre, P. D. (1991). An instrumental motivation in languagestudy: Who says it is not effective? Studies in Second Lnaguage Acquisition, 13, 57-72.

Gardner, R. C. (1985). Social psychology and second language learning. London: Edward Arnold. 
Gardner, R. C. (2001, February). Integrative motivation: Past, present, and future. In Distinguished Lecturer Series. Japan, Tokyo: Temple University.

Gardner, R. C., Masgoret, A. M., Tennant, J., \& Mihic, L. (2004). Integrative motivation: Changes during a yearlong intermediate-level language. Language Learning, 54(1), 1-34.

Gershenson, C. (2002). Contextuality: A philosophical paradigm, with applications to philosophy of cognitive science (Unpublished document, Departmental Technical Report). UK: University of Sussex. Retrieved May 30, 2008, from http://www.cogprints.org/2621/

Greer, R. D. (1999). Is the learning unit a fundamental measure of pedagogy? The Behavior Analyst, 22, 5-16.

Harmer, J. (2003). The practice of English language teaching. Harlow, England: Pearson Education Limited.

Heckhausen, J., \& Heckhausen, J. (Eds.). (2008). Motivation and action. New York, N.Y.: Cambridge University Press.

Hidi, S., Renninger, K. A., \& Krapp, A. (2004). Interest, a motivational variable that combines affective and cognitive functioning. In D. Y. Dai, \& R. J. Sternberg (Eds.), Motivation, emotion, and cognition (pp. 89-115). Mahwah, N.J.: Erlbaum.

Horwitz, E. H. (2000). Teachers and students, students and teachers: An ever-evolving partnership. The Modern Language Journal, 84(4), 523-535.

Inbar, O., Donitsa-Schmidt, S, \& Shohamy, E. (2001). Students' motivation as a function of language learning: The teaching of Arabic in Israel. In Z. Dornyei, \& R. Schmidt (Eds.), Motivation and second language acquisition (Technical Report \#23, pp. 297-311). Honolulu, University of Hawai’i: Second Language Teaching and Curriculum Center.

Janssens, S., \& Mettewie, L. (2004, April). Cross-sectional and longitudinal view of attitudes and motivations to SLL. In The 15th Sociolinguistics Symposium. Newcastle, England. Retrieved May 3, 2008 from http://www.ncl.ac.uk/ss15/papers/paper_ details. php?id=176

Kanno, Y. (2003). Negotiating bilingual and bicultural identities: Japanese returnees betwixt two worlds. Mahwah, N.J.: Erlbaum.

Lamb, M. (2002). Explaining successful language learning in difficult circumstances. Prospect: An Australian Journal of TESOL, $17(2), 35-52$.

Lamb, M. (2004). Integrative motivation in a globalizing world. System, 32 (1), 3-19.

Lamb, M. (2005). It depends on the students themselves: Independent language learning at an Indonesian state school. Language, Culture, and Curriculum, 17(3), 229-245.

Lim, H. Y. (2002). The interaction of motivation, perception, and environment: One EFL learner's experience. Hong Kong Journal of Applied Linguistics, 7(2), 91-106.

Little, D. (2007). Language learner autonomy: Some fundamental considerations revisited. Innovation in Language Learning and Teaching, 1(1), 14-29.

Masgoret, A. M., \& Gardner, R. C. (2003). Attitudes, motivations, and second language learning: A meta-analysis of studies conducted by Gardner and associates. Language Learning, 53(1), 123-163.

McGroarty, M. (2001). Situating second language motivation. In Z. Dornyei, \& R. Schmidt (Eds.), Motivation and second language acquisition (Technical Report \#23, pp. 69-92). Honolulu, University of Hawai'i: Second Language Teaching and Curriculum Center.

Miura, T. (2007). Vocabulary development in relation to motivational trajectory: Retrospective case studies of high proficiency learners (Unpublished manuscript, Temple University, Japan, Tokyo).

Miura, T. (2010). The changes of L2 learning motivation. JALT Journal, 32, 29-53.

Morita, N. (2004). Negotiating participation and identity in second language academic communities. TESOL Quarterly, 38(4), 573-603.

Nairne, J. S. (2000). Psychology: The adaptive mind. Belmont, C.A.: Wordsworth.

Nakata, Y. (2006). Motivation and experience in foreign language learning. Bern, Switzerland: Peter Lang.

Nation, I. S. P. (2001). Learning vocabulary in another language. Cambridge: Cambridge University Press.

Nation, I. S. P. (2007). The vocabulary size test. Retrieved February 27, 2007, from http://www.vuw.ac.nz/lals/staff/paulnation/ nation.aspx

Nikolov, M. (2001). A study of unsuccessful language learners. In Z. Dörnyei, \& R. Schmidt (Eds.), Motivation and second language acquisition (pp. 149-169). Honolulu, H.I., University of Hawaii: Second Language Teaching and Curriculum Center.

Nisbet, D. L., Tindall, E. V., \& Arroyo, A. A. (2005). Language learning strategies and English proficiency of Chinese university students. Foreign Language Annual, 38(10), 100. 
Noels, K. A. (2001a). New orientations in language learning motivation: Towards a model of intrinsic, extrinsic, and integrative orientations and motivation. In Z. Dörnyei, \& R. Schmidt (Eds.), Motivation and second language acquisition (pp. 44-68). Honolulu: University of Hawaii.

Noels, K. A. (2001b). Learning Spanish as a second language: learners' orientations and perceptions of their teachers' communication style. Language Learning, 51(1), 107-144.

Noels, K. A., Pelletier, L. G., Clement, R., \& Vallerand, R. J. (2000). Why are you learning a second language? Motivational orientations and self-determination theory. Language Learning, 50(1), 57-85.

Okada, M., Oxford, R. L., \& Abo, S. (1996). No all alike: Motivation and learning strategies among students of Japanese and Spanish in an exploratory study. In R. Oxford (Ed.), Language learning motivation: Pathways to the new century (pp. 105-119). Honolulu: University of Hawaii, Second Language Teaching and Curriculum Center.

Ortega, L. (2009). Understanding second language acquisition. London, UK: Hodder Education.

Oxford, R. L. (1990). Language learning strategies: What every teacher should know. Boston: Heinle \& Heinle Publishers.

Pagliaro, A. (2002). Motivation and its implications in tertiary Italian studies. In Proceedings of Innovations in Italian teaching workshop (pp. 16-25). Italy: Griffith University. Retrieved October 25, 2003, from http://www.gu.edu.au/centre/italian/ pdf/2_pag.pdf

Pajares, F. (2001). Toward a positive psychology of academic motivation. The Journal of Educational Research, 95(1), 27-35.

Peterson, C. (2000). The future of optimism. American Psychologist, 55(1), 44-55.

Priyadi, A., \& Ismuadi. (1998). Improving the capability of civil servants of East Java Provincial Government. In National Conference. Batu, Malang.

Richards, J. C., \& Lockhart, C. (2004). Reflective teaching in second language classroom. Cambridge: Cambridge University Press.

Ryan, S. (2009). Self and identity in L2 motivation in Japan: The ideal L2 self and Japanese learners of English. In Z. Dörnyei, \& E. Ushioda (Eds.), Motivation, language identity and the L2 self (pp. 120-143). Bristol: Multilingual Matters.

Sawir, E. (2005). Language difficulties of international students in Australia: The effects of prior learning experience. International Education Journal, 6(5), 567-580.

Schmidt, R. (1995). Use of Jappanese in EFL classroom. In Eric Document Reproduction Service (No. EDU. 61280).

Schmidt, R., Boraie, D., \& Kassabgy, O. (1996). Foreign language motivation: Internal structure and external connections. In R. Oxford (Ed.), Language learning motivation: Pathways to the new century (Technical Report \#11, pp. 9-70). Honolulu, University of Hawai'i: Second Language Teaching \& Curriculum Center.

Schumann, J. H. (2001). Appraisal psychology, neurobiology, and language. Annual Review of Applied Linguistics, $21,23-42$.

Schwarz, A. (2000). A Nation in Mailing: Indonesia's search for stability. Boulder, C.O.: Westview Press.

Seidman, I. (2006). Interviewing as qualitative research: A guide for researchers in education and the social sciences (3rd ed.). New York, N.Y.: Teachers College Press.

Seligman, M. E. P., \& Csikszentmihalyi, M. (2000). Positive psychology. American Psychologist, 55(1), 5-14.

Setiyadi, B. (2001). Language learning strategies: Classification \& pedagogical implication. TEFLIN, 12(1).

Sinclair, J., \& Webb, J. (1985). A survey of language needs in Indonesian public administration. London: Overseas Development Administration.

Snyder, C. R. (Ed.). (2000). Handbook of hope: Theory, measures, and applications. San Diego, C.A.: Academic Press.

Spolsky, B. (2000a). Anniversary article: Language motivation revisited. Applied Linguistics, 21(2), 157-169.

Spolsky, B. (2000b). Language motivation revised. Applied Linguistics, 21(2) 157-169.

Squires, T., \& Kawaguchi, Y. (2004). Construction of subjectivity in learners' motivation narratives. In The JALT 2004 Nara: Language Learning for Life. Nara, Japan.

Sternberg, R. J. (2006). A duplex theory of love. In R. J. Sternberg, \& K. Weis (Eds.), The new psychology of love (pp. 184-199). New Haven: Yale University Press.

Stevick, E. W. (1996). Memory, meaning, and method: Some psychological perspectives on language learning (2nd ed.). Florence: Heinle and Heinle Publishers.

Svanes, B. (1987). Motivation and cultural distance in language acquisition. Language Learning, 37(3), 341-59.

Teweles, B. (1996). Motivational differences between Chinese and Japanese learners of English as a foreign language. JALT Journal, 18(2).

Ushioda, E. (2001). Language learning at university: Exploring the role of motivational thinking. In Z. Dörnyei, \& S. Richard (Eds.), Motivation and second language acquisition (pp. 93-125). Honolulu, H.I., University of Hawaii at Manoa: Second Language Teaching and Curriculum Center. 
Ushioda, E. (2007). Motivation, autonomy, and sociocultural theory. In P. Benson (Ed.), Learner autonomy 8: Teacher and learner perspectives (pp. 5-24). Dublin, Ireland: Authentik.

Ushioda, E. (2008). Motivation and good language learners. In C. Griffiths (Ed.), Lessons from good language learners (pp. 19-34). Cambridge: Cambridge University Press.

Ushioda, E. (2009). A person-in-context relational view of Emergent Motivation, self and identity. In Z. Dörnyei, \& E. Ushioda (Eds.), Motivation, language identity, and the L2 self (pp. 215-228). Bristol: Multilingual Matters.

Vandergrift, L. (2005). Relationships among motivation orientations, metacognitive awareness and proficiency in L2 listening. Applied Linguistics, 26(1), 70-89.

Vohs, K., Baumeister, B., Jean, M., Twenge, J., Nelson, N., \& Tice, D. (2008). Making choices impairs subsequent self-control: A limited resource account of decision-making, self-Regulation, and active initiative. Journal of Personality and Social Psychology, 94(5), 883-898.

Webb, V. (2002). English as a second language in South Africa's tertiary institutions. World Englishes, 21(1), 63-81.

Yashima, T., \& Zenuk-Nishide, L. (2008). The impact of learning contexts on proficiency, attitudes, and L2 communication: Creating an imagined international community. System, 36(4), 566-585.

Yin, R. K. (2006). A case study methods. In J. L. Green, G. Camilli, \& P. B. Elmore (Eds.), Handbook of complementary methods in education research (pp. 111-122). Mahwah, N.J.: Erlbaum.

Yin, R. K. (2009). A case study research: Design and methods (4th ed.). Thousand Oaks, C.A.: Sage. 